\title{
Influence of growth hormone therapy on selected dental and skeletal system parameters
}

\author{
Małgorzata Partyka', Renata Chałas², Izabella Dunin- Wilczyńska', Myroslava Drohomyretska³, \\ Maria Klatka ${ }^{4}$ \\ ${ }^{1}$ Department of Orthodontics. Medical University, Lublin, Poland \\ ${ }^{2}$ Department of Conservative Dentistry and Endodontics. Medical University, Lublin, Poland \\ ${ }^{3}$ Department of Orthodontics. Medical University, Kiev, Ukraine \\ ${ }^{4}$ Department of Paediatric Endocrinology and Diabetology. Medical University, Lublin, Poland.
}

Partyka M, Chałas R, Dunin- Wilczyńska I, Drohomyretska M, Klatka M. Influence of growth hormone therapy on selected dental and skeletal system parameters. Ann Agric Environ Med. 2018; 25(1): 60-65. doi: 10.5604/12321966.1233573

\section{Abstract}

Introduction. Growth hormone deficiency (GHD) is one of the main indications for growth hormone therapy. One characteristic of this disease is bone age delay in relation to the chronological age. Pituitary dysfunction negatively affects the growth and development of the jaws and teeth of the child. The secretion of endocrine glands regulates growth, development, and gender differentiation. It also controls the growth of bones and teeth, regulates metabolism of calcium and phosphate, proteins, lipids and carbohydrates. The primary role in the endocrine system is played by the pituitary gland which is responsible for the production of somatotropin[1]. Dysfunction of the pituitary gland has a negative effect on the growth and development of long bones in the body, and may have an adverse effect on the development of maxilla, mandible and dentition of a child. There is some information in the literature that dental age is delayed in short stature children; the replacement of deciduous teeth by permanent teeth is also delayed, and newly erupted permanent teeth often require orthodontic treatment. Applying hormonal therapy positively affects the process of replacement of dentition $[2,3,4,5,6]$.

Objectives. The aim of the study was to assess bone and dental age, as well as analyze the state of dentition in children diagnosed with GH deficiency treated with growth hormone, depending on the duration of treatment.

Materials and method. The study material consisted of 110 children ( 27 males, 83 females), hospitalized for somatotropin hypopituitarism in the Department of Paediatric Endocrinology and Diabetology at the Medical University of Lublin, Poland. The mean birth age was 13 years (156 months) with a standard deviation of 2 years and 6 months (30 months).

47 children (43\%) started treatment with the growth hormone (group starting treatment) and 63 children (57\%) whose treatment was started 2-3 years previously (group in the course of treatment). The control group consisted of $41 \mathrm{generally}$ healthy children (15males, 25 females) with ENT problems, such as hypoacusis and a condition after nasal injury, hospitalized in the Department of Paediatric Otolaryngology at the Medical University of Lublin, Poland. The mean age was 11 years and 5 months ( 137 months) with standard deviation of 2 years and 5 months ( 29 months). Informed consent was obtained from the parents.

The study was approved by the Bioethical Committee at the Medical University of Lublin (Resolution No. KE-0254 /216/2012).

\section{Key words}

somatotropic pituitary hypofunction, malocclusion, dental age

\section{EVALUATION OF BIRTH AGE, SKELETAL AGE AND DENTAL AGE}

Birth age - the number of years, months and days which have passed since the date of birth.

Skeletal age - the evaluation of skeletal maturity on the basis of the time of appearance of ossification nuclei, and the stage of development of the skeletal system. In this study, skeletal age was evaluated according to Greulich-Pyle (GP) atlas [7].

Dental age - correct eruption of teeth is the factor responsible for normal development of the masticatory system. Evaluation of dental age is extremely helpful in dental practice and in correlation with birth age and skeletal age [8].

Address for correspondence: Maria Klatka, Department of Pediatric Endocrinology and Diabetology. Medical University of Lublin, Poland.

E-mail: mariaklatka@wp.pl

Received: 12 July 2016; accepted: 27 September 2016; first published on February 2017
To evaluate dental age in this study, the method by Matiegka and Lukasova was employed. According to this method, dental age is established in the following way: you find out and write down the last chronologically-erupted full group of teeth, also incomplete groups. From the table by Matiegka (for boys) and Lukasova (for girls), read what age corresponds with the number of teeth found in the analyzed groups. Numbers before a comma represent years, and numbers after a comma represent months. Obtained values are summed-up, months and years separately, and the obtained result is divided by the number of dental groups in a specific patient [9].

Calculated values (birth age, skeletal age and dental age) were compared within a studied group (starting treatment and in the course of treatment). In this study, it was analyzed whether the values of skeletal and dental age are affected by the treatment with the growth hormone. Values of birth age and dental age were compared in the studied group and the control group. However, skeletal age was not evaluated in the control group because there was no medical indication 
for taking an X-ray of a palm and wrist. Skeletal and dental age may be compatible, delayed or accelerated in relation to birth age.

Results of the study were introduced in sequence onto a work sheet in the programme Microsoft Excel 2010. Statistical analysis was carried out using Statistica 10 (Statsoft Inc., USA).

\section{RESULTS}

\section{Characteristics of birth age, dental age and skeletal age}

Values of birth age, dental age and skeletal age in the group of ill children and in the control group. Dental and skeletal age was calculated in the group of children with short stature, and dental age in the control group according to the method presented above.

In the control group, the mean age was 137 months with standard deviation of 29 months. The median of birth age was 135 months. Mean dental age was 141 months with a standard deviation of 40 months. The median of the dental age was 144 months. Obtained dental age was compared with birth age.

In the group of short stature children, the mean birth age was 156 months with a standard deviation of 30 months. The median of birth age was 164 months. The mean dental age was 148 months with a standard deviation of 33 months. The median of the skeletal age was 157 month. The obtained dental and skeletal age was compared with birth age.

In the control group the mean difference between dental age and birth age was 3.98 months with a standard deviation of 11.06 months. Obtained results revealed that this is significantly different from $0(\mathrm{p}=0.027)$, which means that dental age is significantly ahead of birth age (Fig. 1).

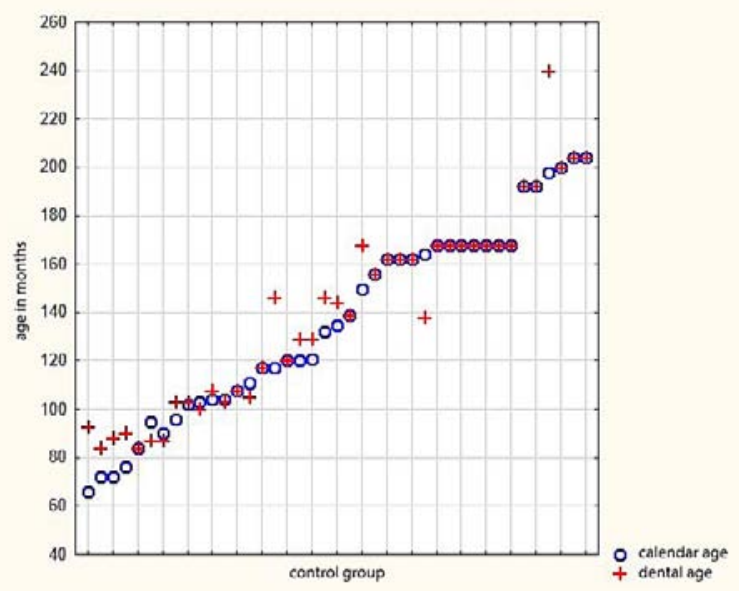

Figure 1. Values of birth age and dental age in control group patients

In the group of short stature children, the mean difference between dental age and birth age was 8.26 months with a standard deviation of 16.02 months. Obtained results reveal that this is significantly different from $0(\mathrm{p}=0.000)$, which means that dental age is significantly delayed in relation to birth age (Fig.2). The mean difference between skeletal age and birth age in this group was 19.83 months with a standard deviation of 15.37 months.

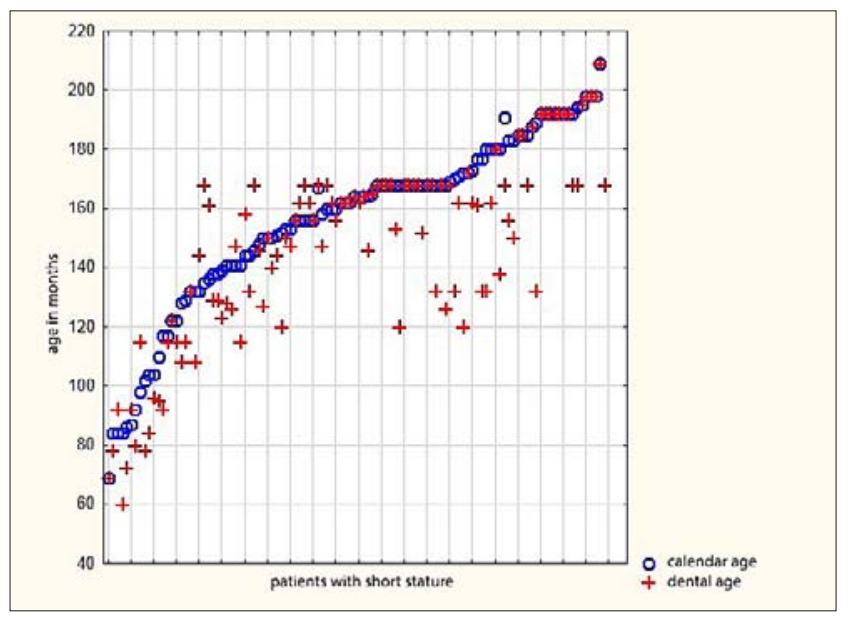

Figure 2. Values of birth age and dental age in short stature patients

Obtained results reveal that this is significantly different from $0(\mathrm{p}=0.000)$ which means that dental age is significantly delayed in relation to birth age (Fig. 3).

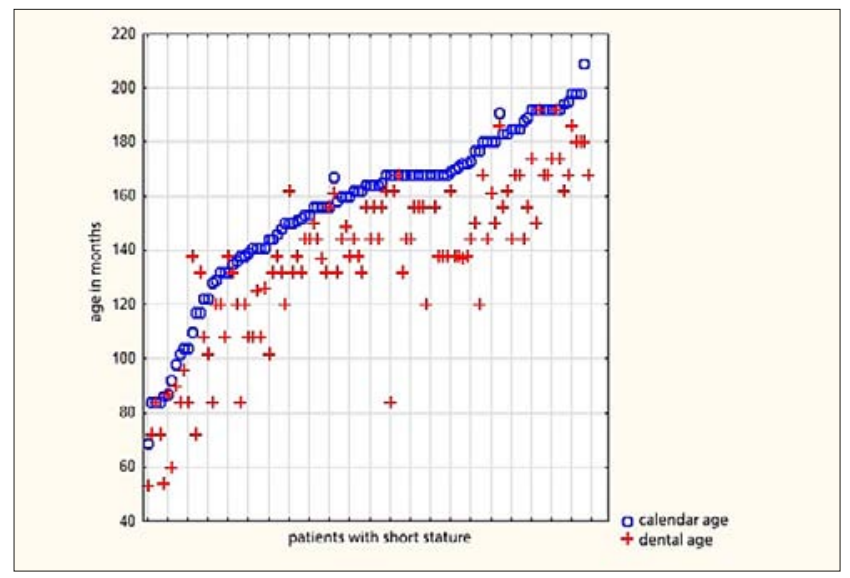

Figure 3. Values of birth age and bone age in short stature patients

\section{Comparison of birth age, dental age and skeletal age in the groups of ill children}

Group starting treatment. In the group starting treatment, the mean birth age was 157.76 months with a standard deviation of 25.30 months. The mean skeletal age was 130.70 months with standard deviation of 22.13 months. A statistically significant difference was revealed between birth age and skeletal age in the group of patients starting treatment $(p=0.000)$ (Fig. 4). The mean birth age was 157.76 months with a standard deviation of 25.30 months. Mean dental age was 138.97 months with a standard deviation of 27.76 months. A statistically significant difference was revealed between birth age and dental age in this group of patients starting treatment $(\mathrm{p}=0.005)$ (Fig. 5).

Group in the course of treatment. In the group in the course of treatment, birth age was 168.98 months with a standard deviation of 26.71 months. The mean dental age was 153.23 months with a standard deviation of 25.72 months. A statistically significant difference was revealed between birth age and skeletal age in this group of patients $(\mathrm{p}=0.007)$ (Fig. 6). 


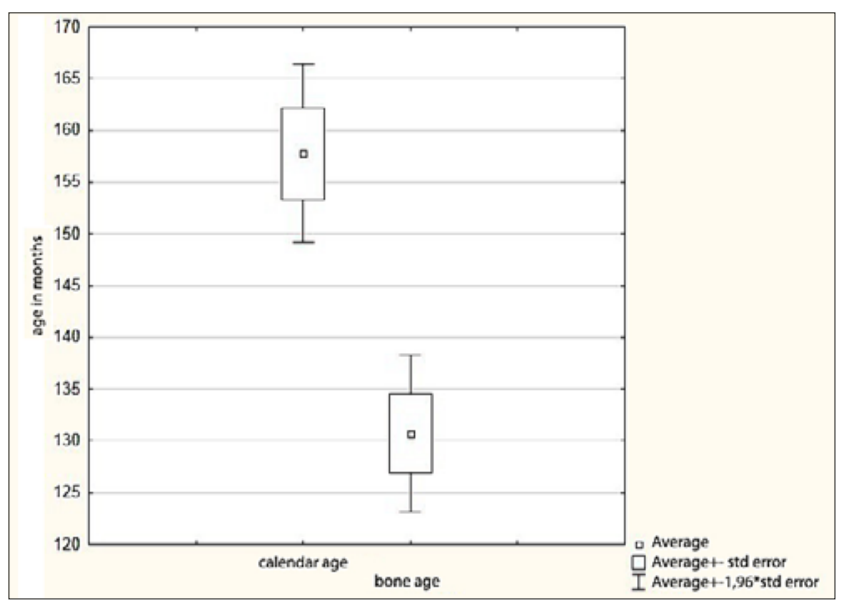

Figure 4. Mean difference between birth and bone age in the group of children starting treatment.

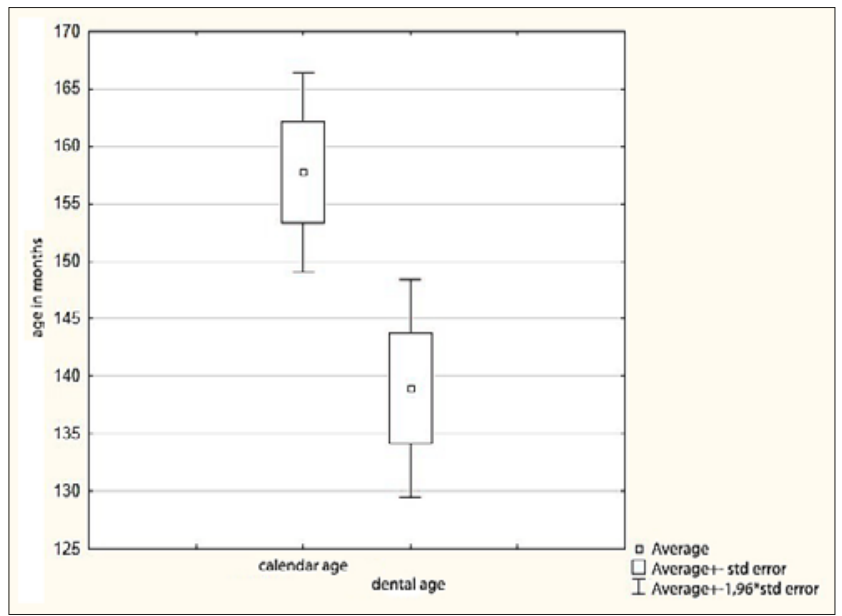

Figure 5. Mean difference between birth and dental age in the group starting treatment

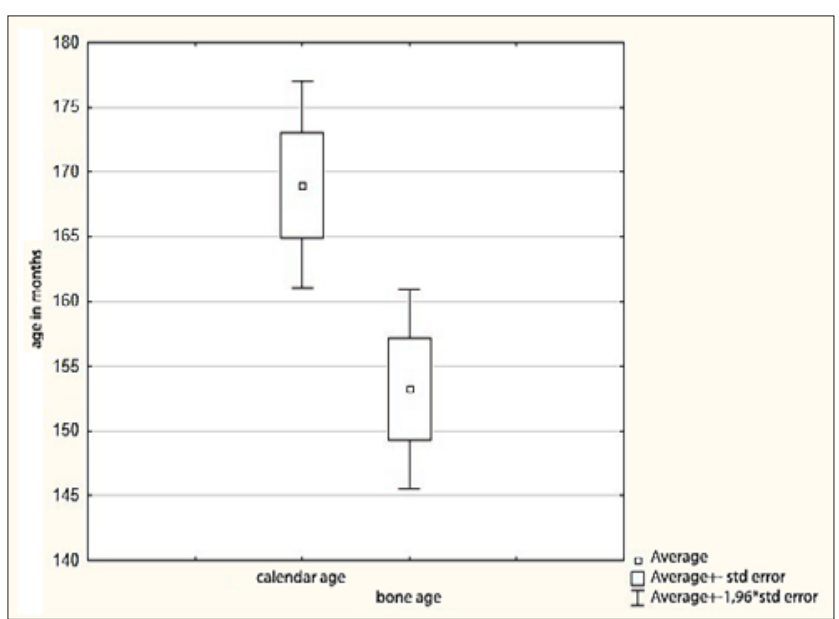

Figure 6. Mean difference between birth age and skeletal age in the group of patients in the course of treatment

In the group with somatotropin hypopituitarism in the course of treatment, the mean birth age was 168.98 months with a standard deviation of 26.71 months. Mean dental age was 166.32 months with a standard deviation of 26.93 months. No statistically significant difference was revealed between birth age and dental age in this group in the course of treatment $(\mathrm{p}=0.645)$ (Fig. 7).

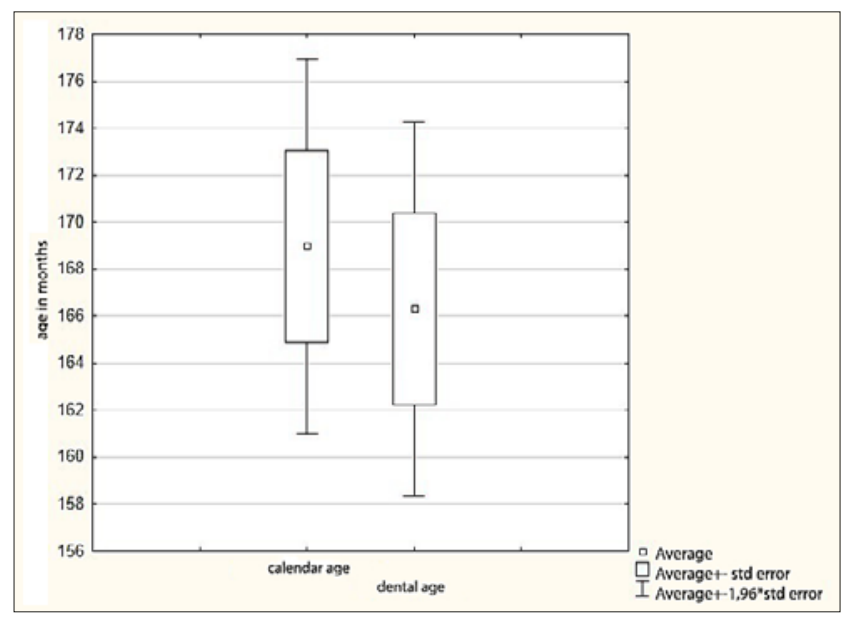

Figure 7. Mean difference between birth age and dental age in the group of patients in the course of treatment

Comparison of differences between birth and dental age in the group of ill children and control group. In the control group, the mean difference between dental age and birth age was 3.98 months with a standard deviation of 11.06 months. In the group of ill children, the mean difference between birth and dental age was 9.70 months with a standard deviation of 16.37 months. A statistically significant difference was revealed between the differences in birth age and dental age in the control group and in short stature children $(\mathrm{p}=0.000)$ (Fig. 8).

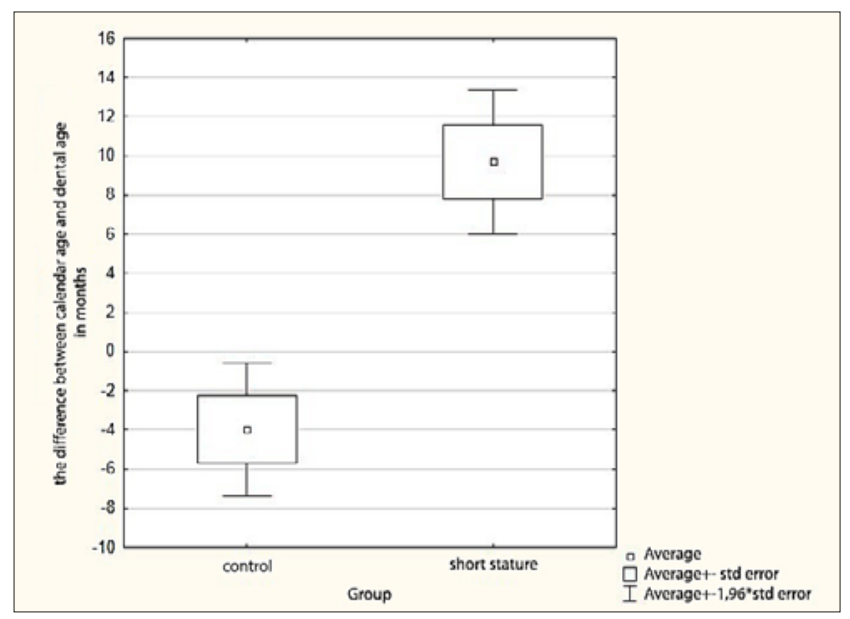

Figure 8. Mean and standard error for the difference between birth age and dental age in the control group and in the group of ill children

Comparison of differences between birth age vs. dental age, and birth age vs. skeletal age in patients at particular stages of treatment. The t-Student test was employed to compare differences between birth age vs. dental age and birth age vs. skeletal age in patients at particular stages of treatment.

In the group starting treatment, the mean of the differences between the birth age and dental age was 18.82 months with a standard deviation of 18.28 months. In the group in the course of treatment, the mean of the difference between birth age and dental age was 2.70 months with a standard deviation of 10.40 months.

In the group starting treatment (49), the mean of the difference between birth age and skeletal age was 27.06 months with a standard deviation of 12.23 months. In 
the group in the course of treatment (61), the mean of the differences between birth age and skeletal age was 16.12 months with a standard deviation of 16.66 months.

In both cases, significant differences were revealed ( $\mathrm{p}=0.000 ; \mathrm{p}=0.002$, respectively). (Figs. 9,10$)$.

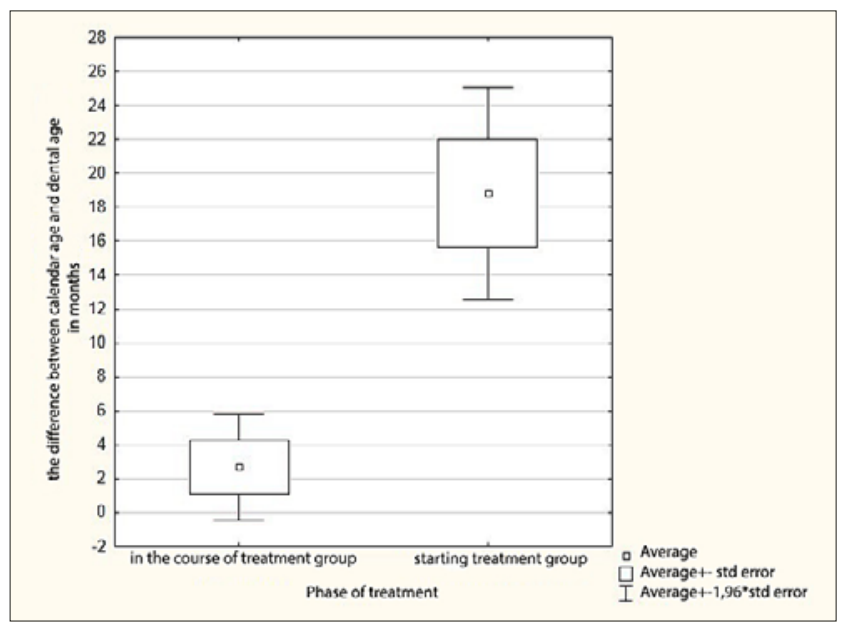

Figure 9. Mean and standard error for the difference between birth age and dental age in the group of ill children

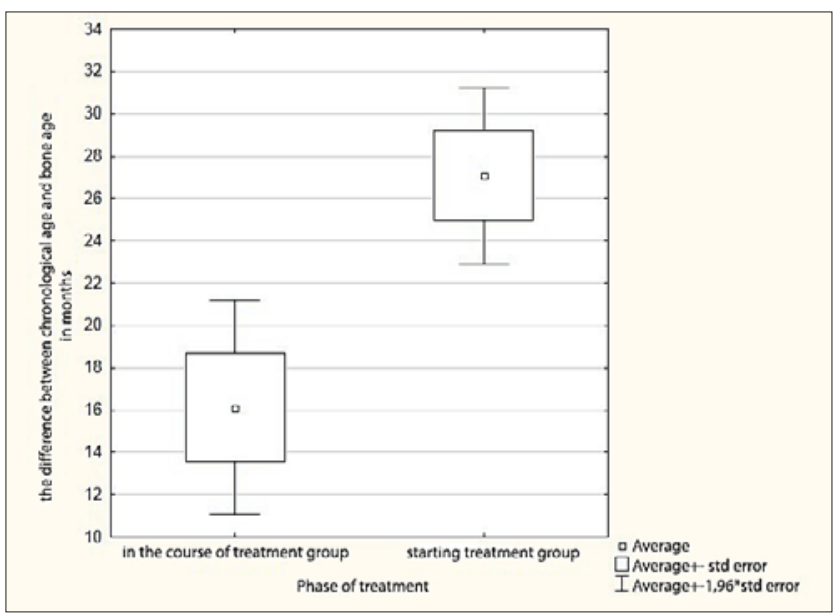

Figure 10. Mean and standard error for the difference between birth age and bone age in the group of ill children

\section{DISCUSSION}

The pituitary gland plays a primary function in the endocrine system. It is responsible for, e.g. the production of growth hormone; therefore, the dysfunction of the pituitary gland negatively affects the general development of the individual. Adverse effects are observed in the growth, proportions and functions of the body. The structure of the facial skeleton and teeth are abnormal, resulting in disturbance in the masticatory system due to abnormal changes in the facial muscular system [10].

Birth age does not reflect fully the physiological development of a child. In order to evaluate precisely the process of development it is necessary to use other criteria: dental age and skeletal age. These factors are extremely important for the diagnosis and planning of therapy by an orthodontist.
According to some authors, there is a relationship between the maturation of the skeletal system and formation of permanent dentition. Flores-Mir et al. revealed the relationship between mineralization of the canine and Mp3 stage (stage of ossification of the middle phalanx of the third finger in the development of bones of the wrist $[11,12]$. Różyło-Kalinowska et al. [13] tested whether there was any relationship between dental age and maturity of the cervical vertebrae. They confirmed the presence of a significant relationship between classification CMV (Cervical Vertebral Maturation) and the development of canine and second premolar teeth. These results suggest that in clinical practice, evaluation of both dental and skeletal age should be recommended [13].

One of the main characteristics of the patient with somatotropin hypopituitarism ( $\mathrm{SH}$ ) is delayed skeletal age, compared with birth age. This is one of the parameters evaluated when $\mathrm{SH}$ is suspected. It helps in making a proper diagnosis and also enables monitoring growth in the course of hormone therapy.

On the basis of the presented study, it was found that a characteristic feature in children with hypopituitarism is delayed skeletal age and dental age in relation to birth age. The studies on the process of tooth eruption and evaluation of dental age may indicate their connection with the secretion of GH [3, 4, 5]. Proffit et al. [14] and Risinger et al. [15] found that the curve of the daily rhythm of tooth eruption is close to the pattern of hormone secretion.

Li et al. [16], on the basis of experiments on laboratory culture of fibroblasts obtained from dental pulp, concluded that growth hormone $(\mathrm{GH})$ generates the process of differentiation of enamel and dentine. Insufficiency of GH results in the delay of skeletal and dental age. This fact is important because the correct process of tooth eruption at the proper time and sequence is a guarantee of normal development of the masticatory system. Smid et al. [17] carried out experiments on genetically modified mice. The size of the dentine matrix in longitudinal section in decalcified first molars was evaluated. Measurements were taken of the teeth of mice with a surplus of GH (Group 1), and with an insufficiency of GH (Group 2). The epithelium of the Hertwig sheath determines the size of a root, due to proliferation in the membrane of epithelium and generating odontoblasts from adjacent dental papilla. The larger size of a root and root dentin in Group 1 may suggest that excessive activity of $\mathrm{GH}$ stimulates greater miotic activity in the epithelium of the Hertwig sheath, which increases its size and differentiation of odontoblasts in the dental papilla. The smaller size of the root (thinner and shorter dentine of the root) in Group 2 (mice with insufficiency of $\mathrm{GH}$ ) suggests that such a phenomenon may result from the decreased activity of hormone and miotic activity in the Hertwig sheath in these mice.

Growth hormone $(\mathrm{GH})$ applied in therapy accelerates skeletal age by stimulating skeleton maturation. Studies by Kostecka [18] reveal that its value increases significantly during treatment with $\mathrm{GH}$, which is consistent with the results of studies by the authors of the presented study. In the studies by Kędzia et al. [19], the increase in skeletal age was also observed. The rate of increase in the first year of treatment was twice as great as before treatment. In successive years, there was a noticeable decrease in the rate of increase. The greatest increase in the rate of increase was observed in the first year of treatment, which is confirmed in studies by other authors [20-22]. 
Kawala et al. [23] evaluated skeletal and dental age in patients treated with GH. Skeletal age was evaluated on the basis of an X-ray film of the palm and wrist, and the radiological atlas by Greulich-Pyle was used to interpret the results. Before starting treatment, skeletal age was delayed in relation to birth age. Two groups of children were compared: Group 1 - patients where the time of treatment was shorter than 1 year, and Group 2 where the time of treatment was longer than 1 year. In Group 1, a statistically significant delay in skeletal age was observed in relation to birth age (mean difference - 37 months). Dental age was also statistically significantly delayed in relation to birth age (according to the Demirjan method the mean delay was 4 months, and according to the Matiegka and Lukasova method the mean delay was 6 months). Skeletal age was also delayed in relation to dental age (mean difference was 26 months according to the Demirjan method and 30 monthss according to the Matiegka and Lukasova method). In Group 2, a delay in skeletal age was also observed in relation to birth age, 25 months, on average, which was statistically significant. Dental age in this group was more advanced than birth age. According to the Demirjan method, acceleration was 8 months, and according to the Matiegka and Lukasova method - 2 months. Skeletal age was delayed in relation to dental age by 37 months, on average.

The results of the current study are consistent with those obtained by other authors. Studies by Kawala et al. [24] confirm that starting therapy with GH and the length of time it was applied affects skeletal age and dental age. In the group of patients where treatment was started early, at the age from 51 months to 79 months, and mean time of treatment lasting 53 months, the acceleration of dental age was about 24 months. In the group of children where the treatment was started at the age from 117 months to 158 months and the mean time of treatment was 15 months, the dental age was slightly delayed in relation to birth age. When treatment is started early and lasts longer the dental age is accelerated.

Studies by Edler [25] confirm that after applying hormonal therapy in short stature children, the delay in tooth eruption is decreased. The length of treatment seems important: a longer time of hormone activity accelerates tooth eruption and dental age. Results of studies by Edler are consistent with studies by Bevis et al.[26], who also observed a significant acceleration of dental age in relation to birth age as a result of hormone therapy on the basis of their own studies. After 1 year of treatment, dental age increased by 12 months, on average. Despite marked improvement, dental age was not finally consistent with birth age - it was still delayed. The authors explained this fact by a considerable delay in dental age at the beginning of treatment. Kjellberg et al. [2], observed in their own studies on a group of short stature boys, that dental age was delayed by about 1 year, which was also confirmed by other authors [3-5]. There is also the opinion in the study by Van Erum et al. [27] that treatment with $\mathrm{GH}$ does not markedly affect the mean value of dental age. However, this theory has not been confirmed by other studies.

In children in the control group of the presented study, dental age was significantly statistically greater than birth age. The mean difference between dental age and birth age was 3.98 months with a standard deviation of 11.06 months. The obtained results revealed that this is significantly different from zero $(p=0.027)$, which means that dental age is really ahead of birth age. These results are consistent with those of other authors. It seems that dental age evaluated in healthy children is head of birth age [28-31]. These results are consistent with the studies by Zatylna et al. [32] carried out on 100 children, where dental age was ahead of birth age by 6 months, on average. Marber et al. [33] found that there is acceleration of dental age by 3 months, on average. According to Wites et al., the mean difference was slightly above 2 months. The cause of this phenomenon seems to be, e.g. ethnic differences $[28,29,34]$, and also an observed tendency to earlier sexual maturity in normally developing children [29, 31, 32, 34].

Hypopituitarism is manifested by some changes within the oral cavity; therefore, the dentist may play an important role in the initial diagnosis of this disease. When problems with the endocrine system are suspected and the medical examination reveals delayed skeletal and dental development, it is very important to take a detailed medical history, inform the patient about observed abnormalities, and refer the patient to a specialist as early as possible. Starting therapy with GH at the proper age of the patient may be very effective in accelerating growth and development of the stomatognathic system.

\section{CONCLUSIONS}

1. Children with hypopituitarism have a delayed skeletal and dental age in relation to birth age.

2. Dental age in children in the control group was ahead of birth age, which is proof of the acceleration phenomenon. 3. A longer period of growth hormone therapy enhances its effect on the cranial-facial complex. This effect is beneficial and leads to reducing disparities in the size of the jaws, and preventing the occurrence of occlusion defects.

\section{REFERENCES}

1. Maria G Vogiatzi, Kenneth C Copeland. Niskie dziecko. Pediatrics In Review. 1998; 2/4: 4-11.

2. Kjellberg H,Beiring M, Wikland K. Craniofacial morphology, dental occlusion, tooth eruption and dental maturity in boys of short stature with or without growth hormone deficiency. Eur J Oral Sci. 2000; 108: 359-367.

3. Cantu G, Buschang PH, Gonzalez JL. Differential growth and maturation in idiopathic growth-hormone-deficient children. Eur J Orthod. 1997; 19: 131-139.

4. Ito RK, Vig KWL, Garn SM, Hopwood NJ, Loos PJ, Spalding PM, et al. The influence of growth hormone therapy on tooth formation in idiopathic short statured children. Am J Orthod Dentofac Orthop. 1993; 103: 358-364.

5. Krekmanova L, Carlstedt-Duke J, Bronnegard M, Marcus C, Grondahl E, Modeer T, et al. Dental maturity in children of short stature with or without growth hormone deficiency. Eur J Oral Sci. 1997; 105: 551-556.

6. Garn SM, Lewis AB, Blizzard RM. Endocrine factors in dental development. J Dent Res 196; 44: 243- 248.

7. Romer T. Zaburzenia wzrastania i dojrzewania płciowego. Medical Tribune Polska, Warszawa 2011.

8. Kiworkowa-Rączkowska E, Różyło-Kalinowska. Value of clinical and radiological evaluation of dentalage. Ace of Dentistry 2006; 4(1): 15-19.

9. Łabiszewska-Jaruzelska F. Ortopedia Szczękowa. Zasady i praktyka. PZWL 1995. p. 24.

10. Melkowska M. Symptoms of endocrine diseases in dental patients. Dent Med Probl. 2011; 48(2): 229-235.

11. Wites M, Kalukin J, Niżankowska-Jędrzejczyk A, Loster BW. Prediction of the growth spurt based on panoramic radiograhps. J Stomatol. 2011; 64: 875-886. 
12. Flores-Mir, Mauricio FR, Orellana MF, Major PW. Association between growth stunting with dental age development and skeletal maturation stage. Angle Orthod. 2005; 75: 935-940.

13. Różyło-Kalinowska I, Kolasa-Rączka A, Kalinowski P. Relationship between dental age according to Demirjian and cervical vertebrae maturity in polish children. Eur J Orthod. 2011; 33: 75-83.

14. Proffit WR, Almeida MA, Lee PCF. What controls the daily rhythm of tooth eruption? In: Davidovitch Z. Biological mechanisms of tooth eruption, resorption \& replacement by implant. Birmingham, AL:EBSCO Media; 1994. p. 335-370.

15. Risinger RK, Proffit WP. Continuous overnight observation of human premolar eruption. 1996; 41: 779-789.

16. Li H, Bartold PM, Zhang CZ. Growth hormone and Insulin-like growth factor I induce bone morphogenetic 2 and 4: A mediator role in tooth and bone formation. Endocrinology 1998; 139: 3855.

17. Smid JR, Rowland JE, Young WG, Coschigano KT, Kopchick JJ, Waters M. Mouse molar dentin size, shape in dependent on growth hormone status. J Dent Res. 2007; 86(5): 463-468.

18. Kostecka L, Wąsikowa R. Retrospektywna kompleksowa ocena efektów leczenia dzieci z somatotropinową niedoczynnością przysadki. Endokrynologia, Diabetologia i Choroby Przemiany Materii Wieku Rozwojowego 2005; 11: 161-169.

19. Kędzia A, Korman E, Obara-Moszyńska M, Rabska-Pietrzak B. Efekt leczenia hormonem wzrostu pacjentów z niedoczynnością somatotropinową w wieku dojrzewania. Endokrynologia Polska 2005; 56: 3246-251

20. Hilczer M. Ocena czynników prognostycznych skuteczności leczenia hormonem wzrostu u dzieci z somatotropinowa niedoczynnością przysadki. Clin Exp Med Lett. 2006; 47: 7-44.

21. Korpal-Szczyrska M, Dorant B, Kamińska H. Ocena wzrostu końcowego pacjentów z somatotropinową niedoczynnościa przysadki leczonych hormonem wzrostu. Endokrynologia, Diabetologia i Choroby Przemiany Materii Wieku Rozwojowego 2006; 1: 31-34.

22. Schonau E, Westermann F, Bauch F. A new and accurate prediction model for growth response to growth hormone treatment in children with growth hormone deficiency. Eur J Endocrinol. 2001; 144: 13-20.
23. Kawala B, Matthews-Brzozowska T, Bieniasz J, Noczyńska A. Dental and skeletal age in children with growth hormone deficiency treated with growth hormone - preliminiary report. Pediatric Endocrinology, Diabetes and Metabolism 2007; 13(4): 210-212.

24. Kawala B, Łopott M, Kubasiewicz P. Wpływ terapii hormonem wzrostu na wybrane parametry zębowe i cefalometryczne. Stom Wsp. 2006; 2: $18-22$.

25. Edler RJ. Dental and skeletal ages in hypopituitary patients. J Dent Res. 1977; 56: 1145.

26. Bevis RR, Hayles AB, Isaacson RJ. Facial growth response to human growth hormone in hypopituitary dwarfs. Angle Orth. 1977; 47: 193.

27. Van Erum R, Mulier G, Carels C. Craniofacial growth and dental maturation in short children born small for gestational age: effect of growth hormone treatment. Horm Res. 1998; 50: 141.

28. Cruz-Landelra A, Linares-Agrote J, Martinez-Rodriguez M, Sol Rodriguez-Calvo M, Otero X, Conchelo 1: Dental age estimation in Spanish and Venezuelan children. Comparison of Demirjian and chail-let's scores. int. J legal Med. 2010; 124: 105-112.

29. Chaillet N, Nyström M, Demirjian D. Comparison of dental maturity in children of different ethnic origins: international maturity curves for clinicians. J Forensic Sci. 2005; 50: 1164-1174.

30. Al-Tuwirqi A, Holcombe T, Seow WK. A study of dental development in caucasian population compared with a non-caucasian population. Eur Arch Paediatr Dent. 2011; 12: 26-30.

31. Różyło-Kalinowska I, Kiworkowa-Rączkowska, Kalinowski P. Dental age in central Poland. Forensic Sci Int. 2008; 174: 207-216.

32. Zatylna N, Rogowska K, Kozanecka A. Porównanie wieku zębowego dziewcząt i chłopców w wieku 6-12 lat z zastosowaniem metody Demirjiana. Dent Med Probl. 2013; 50(1): 64-70.

33. Maber M, Liversidge HM, Hector MP. Accuracy of age estimation of radiographic methods using developing teeth. Forensic Sci int. 2006; 159: 68-73.

34. Liversidge HM, Chaillet N, Mörnstad H, Nyström M, Rowlings K, Taylor J, et al. Timing of Demirjian's tooth formationstages. Ann Hum Biol. 2005; 33: 454-470. 